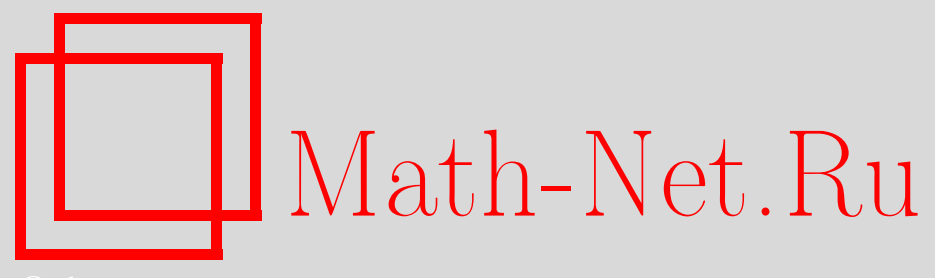

V. V. Privalova, E. Yu. Prosviryakov, Точные peшения Куэтта-Хименца для описания установившегося ползущего конвективного течения вязкой несжимаемой жидкости с учетом теплообмена, Вестн. Сам. гос. техн. ун-та. Сер. Физ.-мат. науки, 2018, номер 3, 532-548

DOI: https://doi.org/10.14498/vsgtu1638

Использование Общероссийского математического портала MathNet.Ru подразумевает, что вы прочитали и согласны с пользовательским соглашением

http://www.mathnet.ru/rus/agreement

Параметры загрузки :

IP : 34.229 .108 .108

26 апреля 2023 г., 06:00:36

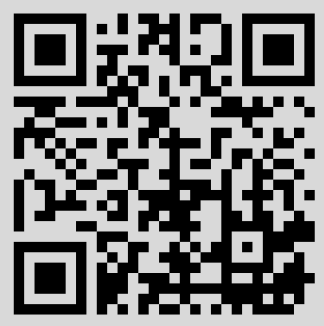


MSC: 76F02, 76F45, 76M45, 76R05, 76U05

\title{
Couette-Hiemenz exact solutions \\ for the steady creeping convective flow of a viscous incompressible fluid with allowance made for heat recovery
}

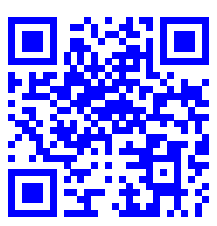

\author{
V. V. Privalova ${ }^{1}$, E. Yu. Prosviryakov ${ }^{1,2}$ \\ 1 Institute of Engineering Science, Urals Branch, Russian Academy of Sciences, \\ 34, Komsomolskaya st., Ekaterinburg, 620049, Russian Federation. \\ 2 Ural Federal University named after the First President of Russia B. N. Yeltsin, \\ 19, Mira st., Ekaterinburg, 620002, Russian Federation.
}

\begin{abstract}
In this paper, we study the steady creeping convective flow of a viscous incompressible fluid in the thin infinite layer. The study of the fluid flow is based on the exact solutions class for the Oberbeck-Boussinesq equations in the Stokes approximation using. The velocity field is described by the Hiemenz exact solution. The temperature field and the pressure field linearly depend on the horizontal (longitudinal) coordinate, it corresponds to the Ostroumov-Birich exact solutions class. The convective motion of a viscous incompressible fluid was induced by tangential stresses on the upper permeable (porous) boundary and thermal source definition at the lower boundary. In addition, the heat exchange according to the Newton-Richmann law takes into account at the upper boundary. The obtained exact solutions describe counterflows in fluids. The stagnant points number in the fluid layer does not exceed three. The formation of counterflows in the fluid is accompanied by sucking and injection of the fluid through the permeable boundary. The larger number of stagnant points presence forms a cellular structure of the streamlines. In addition, the velocity field, which obtained in the solution of the boundary value problem is characterized by localization of the flow near the boundary of the fluid layer (boundary layer). The exact solutions obtained in this paper can be used for the nonlinear Oberbeck-Boussinesq system solving. The Grashof number can take large values, which depends on the geometric anisotropy index for the linearized Oberbeck-Boussinesq system.
\end{abstract}

\section{Research Article}

() (1) The content is published under the terms of the Creative Commons Attribution 4.0 International License (http://creativecommons.org/licenses/by/4.0/)

Please cite this article in press as:

Privalova V. V., Prosviryakov E. Yu. Couette-Hiemenz exact solutions for the steady creeping convective flow of a viscous incompressible fluid, with allowance made for heat recovery, Vestn. Samar. Gos. Tekhn. Univ., Ser. Fiz.-Mat. Nauki [J. Samara State Tech. Univ., Ser. Phys. Math. Sci.], 2018, vol. 22, no. 3, pp. 532-548. doi: 10.14498/vsgtu1638.

Authors' Details:

Valentina V. Privalova (1) http://orcid.org/0000-0002-8648-0900

Cand. Phys. \& Math. Sci.; Researcher; Sector of Nonlinear Vortex Hydrodynamics;

e-mail: valentprival@gmail.com

Evgeny Yu. Prosviryakov (D) http://orcid.org/0000-0002-2349-7801

Dr. Phys. \& Math. Sci., Professor; Head of Sector; Sector of Nonlinear Vortex Hydrodynamics; e-mail: evgen_pros@mail.ru 
Keywords: counterflow, exact solution, Stokes approximation, stagnation point.

Received: $25^{\text {th }}$ July, 2018 / Revised: $21^{\text {st }}$ August, $2018 /$

Accepted: $3^{\text {rd }}$ September, $2018 /$ First online: $4^{\text {th }}$ October, 2018

Introduction. The system consisting of the Boussinesq approximation of the Navier-Stokes equations (Oberbeck-Boussinesq equation system) and the incompressibility equation is one of the most common mathematical systems of equations which describes convective flows of a viscous incompressible fluid [17]. These equations are extremely useful tools for the modeling of convective processes in a fluid [1-7]. The complexity of obtaining exact solutions for the Navier-Stokes equations and their modifications consists in the presence of a substantial (quadratic) nonlinearity of the equations. This nonlinearity is generated by the presence of a convective term in the total derivative.

By now, a certain stock of exact solutions to the Oberbeck-Boussinesq equations has been accumulated [3-18]. Exact solutions describing convective flows of a viscous incompressible fluid allow the qualitative and quantitative characteristics of a moving flow to be re-evaluated. With certain assumptions for highly viscous fluids, the Oberbeck-Boussinesq system can be simplified by neglecting inertial effects due to the predominance of viscous forces (the Stokes approximation) $[8,10-19]$.

The first classes of exact solutions for the natural convection equations were considered by G. A. Ostroumov [20], R. V. Birich [21], and M. I. Schliomis [22]. Later on, the exact solutions presented in [20-22] were generalized in papers and monographs [3, 6-12, 18, 19, 23-30].

The classes of the exact solutions, based on the representation of velocities in the form of linearly dependent functions, were proposed by C. C. Lin for magnetic hydrodynamics [31]. The most complete list of exact solutions obtained in Lin's class for isothermal fluids is found in the review [32].

The Hiemenz exact solution [33] belongs to the class of velocities, linear in part of the coordinates. It is characterized by the existence of a stagnant point in the flow of a viscous incompressible fluid. By now, there have appeared Hiemenz exact solution modifications for isothermal flows [34-36] and convective flows [37-40] of a viscous incompressible fluid. The proposed generalizations of the Hiemenz exact solution family allow one to investigate counterflows in a fluid that are induced by kinematic, dynamic, and thermal perturbations of the fluid flow (boundary conditions) $[8,9,11-17,37-40]$. Additionally, papers studying the existence of stagnant points in the flow and flows near such points are worthy of note.

The assignment of relations between hydrodynamic fields ignoring fluid evaporation and suction predominates among the diversity of boundary conditions on the free (interphase) boundary of the fluid layer [3, 12, 26-30]. Convective flows with fluid evaporation from a free surface can be simulated by replacing it with a permeable non-deformable boundary [7, 37]. This approach is implemented for the description of convection in magnetic fluids [37-40] and nanofluids with various properties [37-40] by numerical integration of the Oberbeck-Boussinesq equations.

To eliminate the deficiency of exact solutions for the Oberbeck-Boussinesq 
system, an exact solution for the stationary creeping convective flow of a horizontal infinite layer of a viscous incompressible fluid is obtained in this paper. Tangential stresses are given on the upper thermally insulated permeable layer boundary, constant pressure and the Newton-Richman law of heat exchange being taken into account at the upper boundary. The no-slip condition is satisfied and the heat source is given at the lower boundary. The obtained exact solution is studied in detail for the diagnostics of the stratification of hydrodynamic fields describing the modification of the Couette-Hiemenz flow [15-17].

1. Problem statement. The plane motion equations of a viscous incompressible fluid in an infinite layer with plane boundaries (Fig. 1), which describe the effect of temperature on the distribution of hydrodynamic fields, are considered in the Boussinesq approximation [1, 15-17] as

$$
\begin{gathered}
\frac{\partial V_{x}}{\partial t}+V_{x} \frac{\partial V_{x}}{\partial x}+V_{z} \frac{\partial V_{x}}{\partial z}=-\frac{\partial P}{\partial x}+\nu\left(\frac{\partial^{2} V_{x}}{\partial x^{2}}+\frac{\partial^{2} V_{x}}{\partial z^{2}}\right) ; \\
\frac{\partial V_{z}}{\partial t}+V_{x} \frac{\partial V_{z}}{\partial x}+V_{z} \frac{\partial V_{z}}{\partial z}=-\frac{\partial P}{\partial z}+\nu\left(\frac{\partial^{2} V_{z}}{\partial x^{2}}+\frac{\partial^{2} V_{z}}{\partial z^{2}}\right)+g \beta T ; \\
\frac{\partial T}{\partial t}+V_{x} \frac{\partial T}{\partial x}+V_{z} \frac{\partial T}{\partial z}=\chi\left(\frac{\partial^{2} T}{\partial x^{2}}+\frac{\partial^{2} T}{\partial z^{2}}\right) ; \\
\frac{\partial V_{x}}{\partial x}+\frac{\partial V_{z}}{\partial z}=0 .
\end{gathered}
$$

Here, $V_{x}$ and $V_{z}$ are velocities parallel to the $O x$ and $O z$ Cartesian axes; $P$ is deviation of pressure from hydrostatic referred to constant average fluid density $\rho ; T$ is deviation from the average temperature; $\nu, \chi$ are the kinematic viscosity coefficient and the thermal diffusivity coefficient of the fluid, respectively; $g$ is acceleration of gravity; $\beta$ is the temperature coefficient of the volumetric expansion of the fluid [1].

The exact solution of the Oberbeck-Boussinesq system (1) is sought for the nonstationary case [15-17] in the form

$$
\begin{aligned}
& V_{x}(x, z, t)=U(z, t)+u(z, t) x \\
& V_{z}(z, t)=w(z, t) \\
& T(x, z, t)=T_{0}(z, t)+T_{1}(z, t) x \\
& P(x, z, t)=P_{0}(z, t)+P_{1}(z, t) x .
\end{aligned}
$$

The solution class (2) generalizes the classical Hiemenz exact solution [3, 8, 1117, 23, 31, 35-37]. We substitute expressions (2) into the equations system (1),

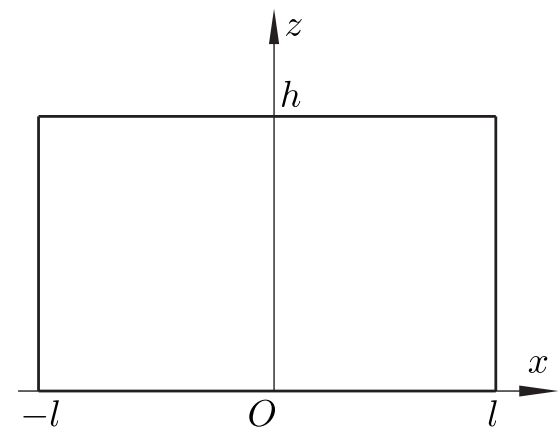

Figure 1. The problem statement 
and we obtain the following equation system:

$$
\begin{gathered}
\frac{\partial U}{\partial t}+\frac{\partial u}{\partial t} x+(U+u x) u+w\left(\frac{\partial U}{\partial z}+\frac{\partial u}{\partial z} x\right)=-P_{1}+\nu\left(\frac{\partial^{2} U}{\partial z^{2}}+\frac{\partial^{2} u}{\partial z^{2}} x\right) \\
\frac{\partial w}{\partial t}+w \frac{\partial w}{\partial z}=-\frac{\partial P_{0}}{\partial z}-\frac{\partial P_{1}}{\partial z} x+\nu \frac{\partial^{2} w}{\partial z^{2}}+g \beta\left(T_{0}+T_{1} x\right) \\
\frac{\partial T_{0}}{\partial t}+\frac{\partial T_{1}}{\partial t} x+(U+u x) T_{1}+w\left(\frac{\partial T_{0}}{\partial z}+\frac{\partial T_{1}}{\partial z} x\right)=\chi\left(\frac{\partial^{2} T_{0}}{\partial z^{2}}+\frac{\partial^{2} T_{1}}{\partial z^{2}} x\right) \\
u+\frac{\partial w}{\partial z}
\end{gathered}
$$

Using the method of undetermined coefficients (linear independence of the functions 1 and $x$ ), we write separately the free terms and coefficients for the horizontal (longitudinal) coordinate $x$. We obtain a system of gradient and nonlinear parabolic equations of the dimension $(1+1)$ :

$$
\begin{gathered}
\frac{\partial U}{\partial t}+U u+w \frac{\partial U}{\partial z}=-P_{1}+\nu \frac{\partial^{2} U}{\partial z^{2}} \\
\frac{\partial u}{\partial t}+u^{2}+w \frac{\partial u}{\partial z}=\nu \frac{\partial^{2} u}{\partial z^{2}} \\
\frac{\partial w}{\partial t}+w \frac{\partial w}{\partial z}=-\frac{\partial P_{0}}{\partial z}+\nu \frac{\partial^{2} w}{\partial z^{2}}+g \beta T_{0} \\
\frac{\partial P_{1}}{\partial z}-g \beta T_{1}=0 \\
\frac{\partial T_{0}}{\partial t}+U T_{1}+w \frac{\partial T_{0}}{\partial z}=\chi \frac{\partial^{2} T_{0}}{\partial z^{2}} \\
\frac{\partial T_{1}}{\partial t}+u T_{1}+w \frac{\partial T_{1}}{\partial z}=\chi \frac{\partial^{2} T_{1}}{\partial z^{2}} \\
u+\frac{\partial w}{\partial z}
\end{gathered}
$$

In what follows, we assume that the solutions are stationary functions, i.e. that all the unknown functions $U, u, w, P_{0}, P_{1}, T_{0}$ and $T_{1}$ depend only on the $z$-coordinate. We denote the partial derivatives with respect to $z$ by a prime.

Let us consider the approximation of system (3) for highly viscous fluids. This approximation is referred to as the Stokes approximation [1, 2, 5, 12-17, 19]. Thus we will seek an exact solution neglecting the effect of the convective derivative in all equations (1) describing the motion of convective flows of a viscous incompressible fluid. We write the equation system of a convective fluid flow (3) for the Stokes approximation in the order of integration:

$$
\begin{gathered}
u^{\prime \prime}=0 ; \\
w^{\prime}=-u ; \\
T_{0}^{\prime \prime}=0 ; \\
\nu w^{\prime \prime}=P_{0}^{\prime}-g \beta T_{0} ; \\
T_{1}^{\prime \prime}=0
\end{gathered}
$$




$$
\begin{aligned}
& P_{1}^{\prime}=g \beta T_{1} \\
& \nu U^{\prime \prime}=P_{1}
\end{aligned}
$$

The general exact polynomial solution of system (4) has the form

$$
\begin{gathered}
u=C_{1} z+C_{2} ; \\
w=-C_{1} \frac{z^{2}}{2}-C_{2} z+C_{3} ; \\
T_{0}=C_{4} z+C_{5} ; \\
P_{0}=-\nu\left(C_{1} z+C_{2}\right)+g \beta\left(C_{4} \frac{z^{2}}{2}+C_{5} z\right)+C_{6} ; \\
T_{1}=C_{7}+C_{8} ; \\
P_{1}=g \beta\left(C_{7} \frac{z^{2}}{2}+C_{8} z\right)+C_{9} ; \\
U=\frac{1}{\nu}\left[g \beta\left(C_{7} \frac{z^{4}}{4 !}+C_{8} \frac{z^{3}}{3 !}\right)+C_{9} \frac{z^{2}}{2 !}\right]+C_{10} z+C_{11} .
\end{gathered}
$$

We write the boundary conditions and solve the boundary value problem for equations system (4). Assume that at the lower boundary $(z=0)$, the no-slip condition is satisfied and the temperature change is given by a linear form as

$$
\begin{gathered}
V_{x}(0)=V_{z}(0)=0 \\
T(0)=A+B x .
\end{gathered}
$$

On the upper permeable boundary of the fluid layer $(z=h)$, the non-uniform tangential stresses, the pressure change and heat exchange according to the NewtonRichman law are given as [1]

$$
\begin{gathered}
\left.\frac{d V_{x}}{d z}\right|_{z=h}=\tau+\sigma x \\
\left.\kappa \frac{d T}{d z}\right|_{z=h}=-a T \\
P(h)=S+S_{1} x
\end{gathered}
$$

The boundary conditions (6), (7) are written in view of the form of solutions (2) as

$$
\begin{gathered}
U(0)=u(0)=w(0)=0 ; \\
T_{0}(0)=A ; \\
T_{1}(0)=B ; \\
\left.\frac{d U}{d z}\right|_{z=h}=\tau ; \\
\left.\frac{d u}{d z}\right|_{z=h}=\sigma ; \\
\left.\kappa \frac{d T_{0}}{d z}\right|_{z=h}=-a T_{0}(h) ;
\end{gathered}
$$




$$
\begin{gathered}
\left.\kappa \frac{d T_{1}}{d z}\right|_{z=h}=-a T_{1}(h) ; \\
P_{0}(h)=S \\
P_{1}(h)=S_{1} .
\end{gathered}
$$

We substitute the boundary conditions (8) into system (5) and obtain the exact solution of the boundary value problem,

$$
\begin{gathered}
u=\sigma z ; \\
w=-\sigma \frac{z^{2}}{2} ; \\
T_{0}=A\left(1-\frac{a z}{\kappa+a h}\right) ; \\
P_{0}=-\frac{a A g \beta z^{2}}{2(\kappa+a h)}+z(A g \beta-\nu \sigma)-\frac{A h g \beta(2 \kappa+a h)}{2(\kappa+a h)}+h \nu \sigma+S ; \\
T_{1}=B\left(1-\frac{a z}{\kappa+a h}\right), P_{1}=-\frac{a B g \beta z^{2}}{2(\kappa+a h)}+B g \beta z-\frac{B h g \beta(2 \kappa+a h)}{2(\kappa+a h)}+S_{1} ; \\
U=-\frac{a^{2} g \beta z^{4}}{4 ! \nu(\kappa+a h)}+\frac{z^{2}}{3 ! \nu}\left(S_{1}-\frac{B h g \beta(2 \kappa+a h)}{2 \nu}\right)+ \\
\left.+\frac{B h^{2} g \beta(3 \kappa+a h)}{6 \nu(\kappa+a h)}+\tau+\frac{h S_{1}}{\nu}\right) .
\end{gathered}
$$

The exact solution (9) for the hydrodynamic fields (2) is reduced to the dimensionless form as follows:

$$
\begin{gathered}
u=\frac{\zeta \operatorname{Re} \delta}{\mathrm{Gr}} Z ; \\
w=-\frac{\zeta \operatorname{Re} \delta^{2}}{2 \mathrm{Gr}} Z^{2} ; \\
T_{0}=\xi\left(1-\frac{\operatorname{Bi} \delta}{\operatorname{Bi} \delta+1} Z\right) ; \\
P_{0}=-\frac{\operatorname{Bi} \delta^{2}}{2(\operatorname{Bi} \delta+1)} Z+\left(\delta-\frac{\zeta \operatorname{Re} \delta}{\mathrm{Gr} \xi}\right) Z-\frac{\delta(\operatorname{Bi} \delta+2)}{2(\mathrm{Bi} \delta+1)}+\frac{\zeta \operatorname{Re} \delta+\eta \mathrm{Hg}}{\mathrm{Gr} \xi} ; \\
T_{1}=1-\frac{\mathrm{Bi} \delta}{\mathrm{Bi} \delta+1} Z ; \\
P_{1}=-\frac{\delta(\mathrm{Bi} \delta+2)}{2(\mathrm{Bi} \delta+1)} Z^{2}+\frac{\mathrm{Hg}}{\mathrm{Gr}} ; \\
\frac{\delta^{4} Z^{4}}{4 ! \mathrm{Bi}(\mathrm{Bi} \delta+1)}+\frac{\delta^{3} Z^{3}}{3 !}+\left(\frac{\delta^{2} \mathrm{Hg}}{2 \mathrm{Gr}}-\frac{\delta^{3}(\mathrm{Bi} \delta+2)}{4(\mathrm{Bi} \delta+1)}\right) Z^{2}+ \\
+\left(\frac{\delta^{3}(\mathrm{Bi} \delta+3)}{6(\mathrm{Bi} \delta+1)}+\frac{\operatorname{Re} \delta-\delta^{2} \mathrm{Hg}}{\mathrm{Gr}}\right) Z .
\end{gathered}
$$

Here, $Z=z / h$ is a dimensionless variable; $\delta=h / l$ is the geometric anisotropy parameter of the viscous incompressible fluid layer; $\xi=A /(B l), \zeta=\sigma l / \tau, \eta=$ 
$S /\left(S_{1} l\right) ; \mathrm{Bi}=a l / \kappa, \mathrm{Hg}=S_{1} l^{3} / \nu^{2}, \mathrm{Gr}=g \beta B l^{4} / \nu^{2}$, and $\operatorname{Re}=\tau l^{2} / \nu$ are the Bio, Hagen, Grashof and Reynolds dimensionless numbers, respectively.

2. Velocity field analysis. We investigate the obtained component of the horizontal velocity $U$. This function is a homogeneous quartic polynomial; therefore, it can be written in a multiplicative form as

$$
U(Z)=Z \cdot f(Z)
$$

Here, the polynomial is defined by the formula

$$
\begin{aligned}
f(Z)=-\frac{\delta^{4}}{4 ! \operatorname{Bi}(\operatorname{Bi} \delta+1)} Z^{3}+\frac{\delta^{3}}{3 !} Z^{2}+\left(\frac{\delta^{2} \mathrm{Hg}}{2 \mathrm{Gr}}-\frac{\delta^{3}(\mathrm{Bi} \delta+2)}{4(\mathrm{Bi} \delta+1)}\right) Z+ & \\
+ & \frac{(\mathrm{Bi} \delta+3)}{3 !(\mathrm{Bi} \delta+1)} \delta^{3}+\frac{\operatorname{Re} \delta-\delta^{2} \mathrm{Hg}}{\mathrm{Gr}} .
\end{aligned}
$$

We apply the Cardano formula to the determination of the equation roots. We write the polynomial $f(Z)$ in the form

$$
f(Z)=\alpha_{1} Z^{3}+\alpha_{2} Z^{2}+\alpha_{3} Z+\alpha_{4}=0,
$$

where the coefficients of the polynomial $f(Z)$ are defined as follows:

$$
\begin{array}{ll}
\alpha_{1}=-\frac{\delta^{4}}{4 ! \operatorname{Bi}(\operatorname{Bi} \delta+1)} ; & \alpha_{2}=\frac{\delta^{3}}{3 !} ; \\
\alpha_{3}=\frac{\delta^{2} \mathrm{Hg}}{2 \mathrm{Gr}}-\frac{\delta^{3}(\mathrm{Bi} \delta+2)}{4(\mathrm{Bi} \delta+1)} ; & \alpha_{4}=\frac{(\operatorname{Bi} \delta+3)}{3 !(\mathrm{Bi} \delta+1)} \delta^{3}+\frac{\operatorname{Re} \delta-\delta^{2} \mathrm{Hg}}{\mathrm{Gr}} .
\end{array}
$$

The discriminant of the cubic polynomial is determined up to a sign by the determinant of the following matrix [41]:

$$
A=\left|\begin{array}{ccccc}
1 & \alpha_{2} & \alpha_{3} & \alpha_{4} & 0 \\
0 & \alpha_{1} & \alpha_{2} & \alpha_{3} & \alpha_{4} \\
3 & 2 \alpha_{2} & \alpha_{3} & 0 & 0 \\
0 & 3 \alpha_{1} & 2 \alpha_{2} & \alpha_{3} & 0 \\
0 & 0 & 3 \alpha_{1} & 2 \alpha_{2} & \alpha_{3}
\end{array}\right| .
$$

We calculate the determinant of the matrix $A$ and obtain an expression for the discriminant of the cubic polynomial:

$$
D=\operatorname{det} A=-4 \alpha_{2}^{3} \alpha_{4}+\alpha_{2}^{2} \alpha_{3}^{2}-4 \alpha_{3}^{3} \alpha_{1}+18 \alpha_{1} \alpha_{2} \alpha_{3} \alpha_{4}-27 \alpha_{1}^{2} \alpha_{4}^{2} .
$$

Using the formulas for the coefficients of the polynomial $f(Z)(11)$, we write this condition in terms of dimensionless numbers as

$$
\begin{array}{r}
\frac{1}{18}\left(\frac{\mathrm{Hg}}{2 \mathrm{Gr}}-\frac{\delta(\mathrm{Bi} \delta+2)}{4(\mathrm{Bi} \delta+1)}\right)^{2}-\frac{1}{27}\left(\frac{\mathrm{Re}-\mathrm{Hg} \delta}{\mathrm{Gr}}+\frac{\delta(\mathrm{Bi} \delta+3)}{6(\mathrm{Bi} \delta+1)}\right)+ \\
+\frac{1}{\mathrm{Bi}(\mathrm{Bi} \delta+1)}\left[\frac{1}{3}\left(\frac{\mathrm{Hg}}{2 \mathrm{Gr}}-\frac{\delta(\mathrm{Bi} \delta+2)}{4(\mathrm{Bi} \delta+1)}\right)^{3}-\right.
\end{array}
$$




$$
\begin{aligned}
-\frac{1}{4}\left(\frac{\mathrm{Hg}}{2 \mathrm{Gr}}-\frac{\delta(\mathrm{Bi} \delta+2)}{4(\mathrm{Bi} \delta+1)}\right)\left(\frac{\operatorname{Re}-\mathrm{Hg} \delta}{\mathrm{Gr}}+\frac{\delta(\mathrm{Bi} \delta+3)}{6(\operatorname{Bi} \delta+1)}\right)- \\
\left.-\frac{3}{32 \mathrm{Bi}(\mathrm{Bi} \delta+1)}\left(\frac{\operatorname{Re}-\mathrm{Hg} \delta}{\mathrm{Gr}}+\frac{\delta(\mathrm{Bi} \delta+3)}{6(\mathrm{Bi} \delta+1)}\right)^{2}\right]>0 .
\end{aligned}
$$

The condition for the existence of three real roots of the cubic polynomial $f(Z)$ is as follows:

$$
D>0 \text {. }
$$

For example, for $\mathrm{Bi}=-10, \operatorname{Re}=100$, and $\delta=0.01$, when the Grashof number varies within the interval $(-1000 ; 1000)$ and the Hagen number varies within $(-2000 ; 2000)$, the root existence region has the form as in Fig. 2. In order that the obtained roots belong to the interval $Z \in(0 ; 1)$, we perform the following transformation, with the introduction of an auxiliary variable:

$$
Y=\frac{Z-Z_{\min }+\varepsilon}{Z_{\max }-Z_{\min }+2 \varepsilon},
$$

where $Z_{\min }$ and $Z_{\max }$ are the smallest and largest roots of equation (10), $\varepsilon$ is any arbitrarily small positive number.

The graph of the velocity component $U$ with three roots in the interval $Z \in$ $(0 ; 1)$ is shown in Fig. 3 (curve 1 ).

Similarly to the above arguments, the polynomial $f(Z)$ will have one real root on the interval $Z \in(0 ; 1)$ (and two complex conjugates) under the condition $D<0$ and with the corresponding transformation

$$
Y=\frac{Z-Z_{1}+\varepsilon}{2 \varepsilon},
$$

where $Z_{1}$ is the unique real root of equation (10) (Fig. 3, curve 3).

The polynomial $f(Z)$ may have either two coinciding real roots and one different from them, or three matching real roots in the interval $Z \in(0 ; 1)$ when the condition $D=0$ is satisfied. After a transformation analogous to (12) and (13), the obtained roots may be localized on the interval $(0 ; 1)$. Curve 2 in Fig. 3 shows the two existing roots of the function $U$ on the interval under study.

The streamlines for the obtained flow velocities for a different number of stagnant points are shown in Figs. 4-6. The figures show the inflow (Fig. 4) or outflow (Figs. 5 and 6) of the fluid at the upper boundary and the existence of counterflows in the fluid layer. The fluid inflow or outflow at the upper boundary will depend on the sign of the transverse velocity $V_{z}$.

Fig. 7 shows the form of the kinetic energy for the cases of three, two, and one real roots of the function $U$, respectively.

3. Pressure and temperature field analysis. Let us analyze the function $P_{0}$. With a certain choice of the flow parameters and the fulfillment of the condition

$$
[\operatorname{Re} \zeta(1+\operatorname{Bi} \delta)-\operatorname{Gr} \xi]^{2}>-2 \operatorname{Gr} \operatorname{BiHg} \eta \xi(1+\operatorname{Bi} \delta)
$$

there may be regions of positive and negative pressure in the fluid layer. "Positive" and "negative" mean the pressure value relative to that preset at the upper 
boundary, which is equal to atmospheric pressure. Similarly, the pressure gradient $P_{1}$ may change the sign on the interval $Z \in(0 ; 1)$. The pressure isolines are shown in Fig. 8.

The temperature study for the boundary value problem is trivial, since both components of the temperature field depend linearly on the transverse coordinate $Z$. A qualitative view of the temperature isolines is shown in Fig. 9.

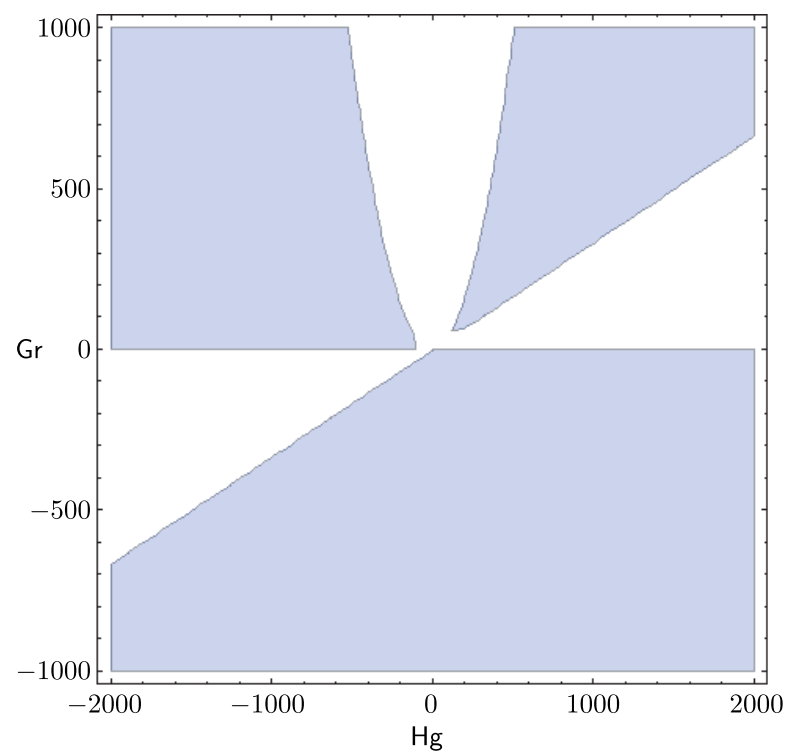

Figure 2. The existence domains of the polynomial roots $f(Z)$ for the defined values of the parameters $\mathrm{Bi}=-10, \operatorname{Re}=100, \delta=0.01$

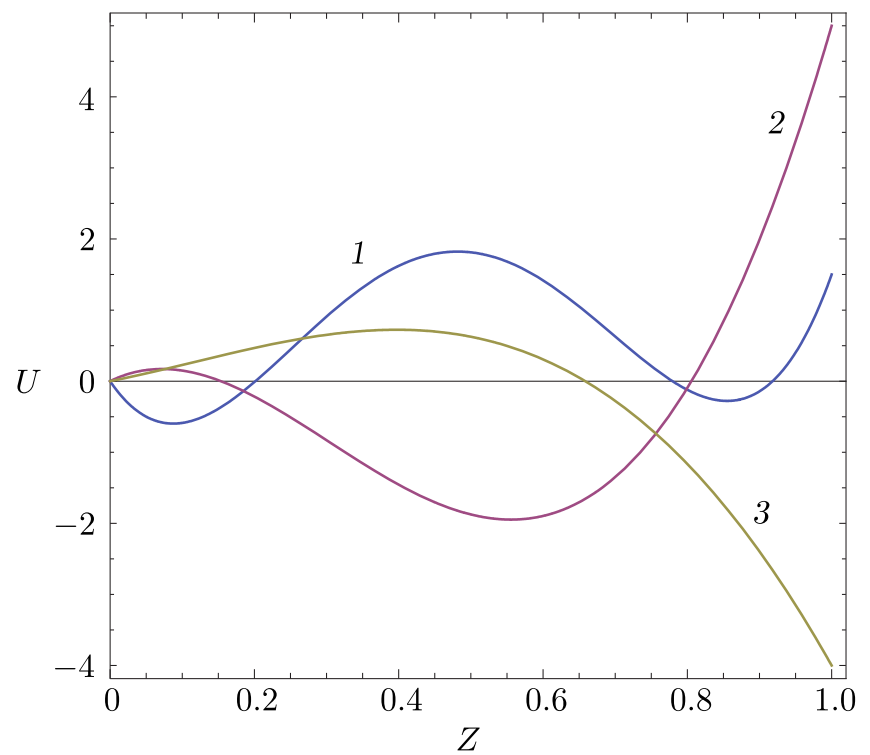

Figure 3. The graphs of the function $U$ with three (curve 1), two (curve 2) and one (curve 3) real roots 


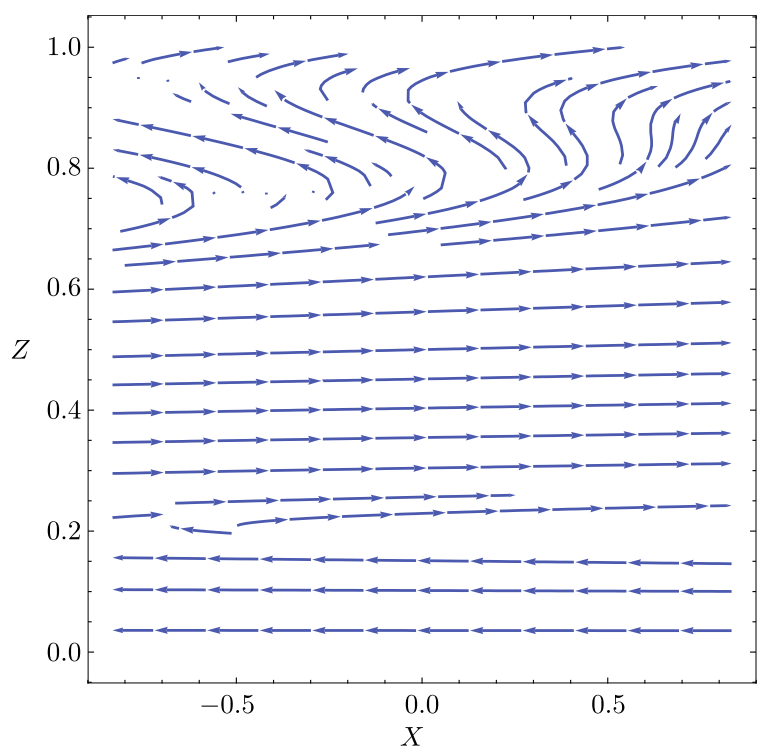

Figure 4. Streamlines for the case of three stagnant points. Inflow of fluid to the upper boundary

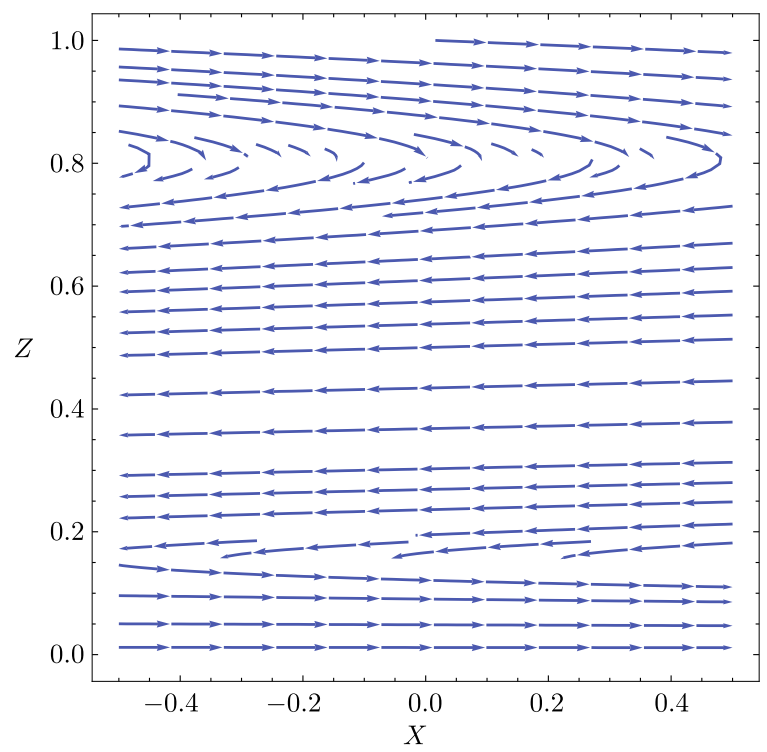

Figure 5. Streamlines for the case of two stagnant points. Fluid outflow from the upper boundary 


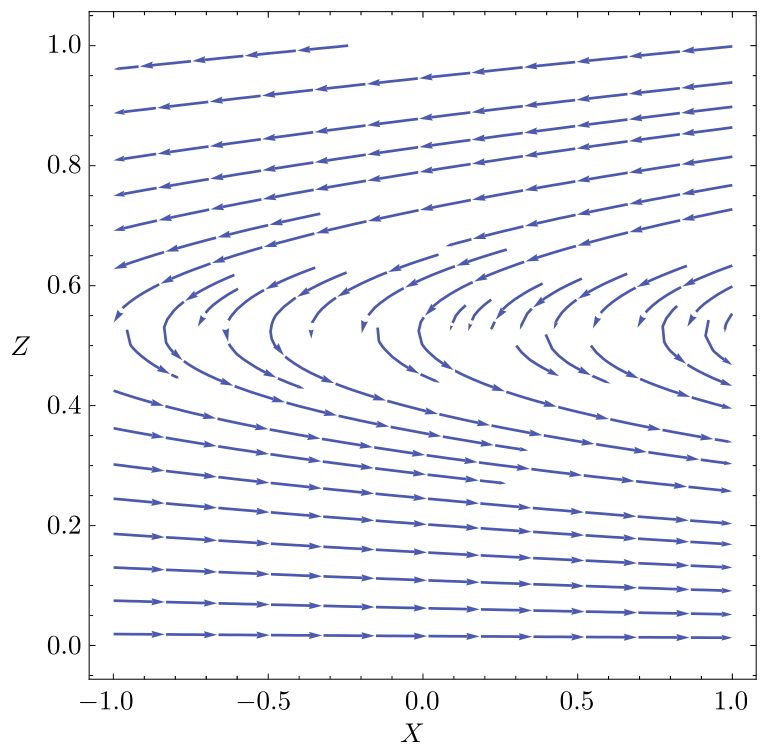

Figure 6. Streamlines for the case of one stagnant point. Fluid outflow from the upper boundary

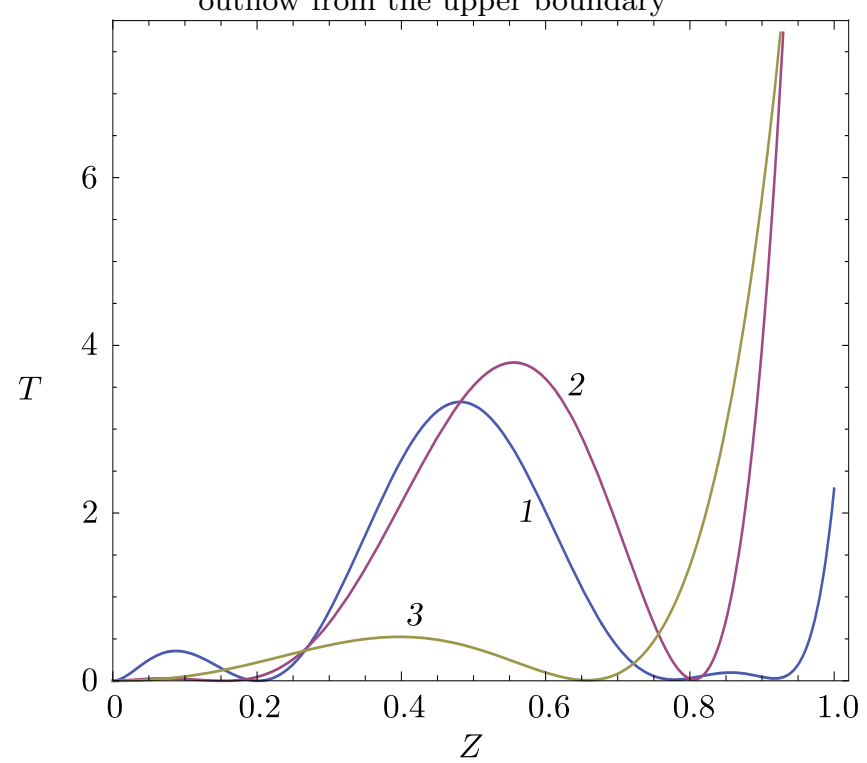

Figure 7. Kinetic energy for the cases of three roots (curve 1), two roots (curve 2) and one root (curve 3 ) of the function $U$ 


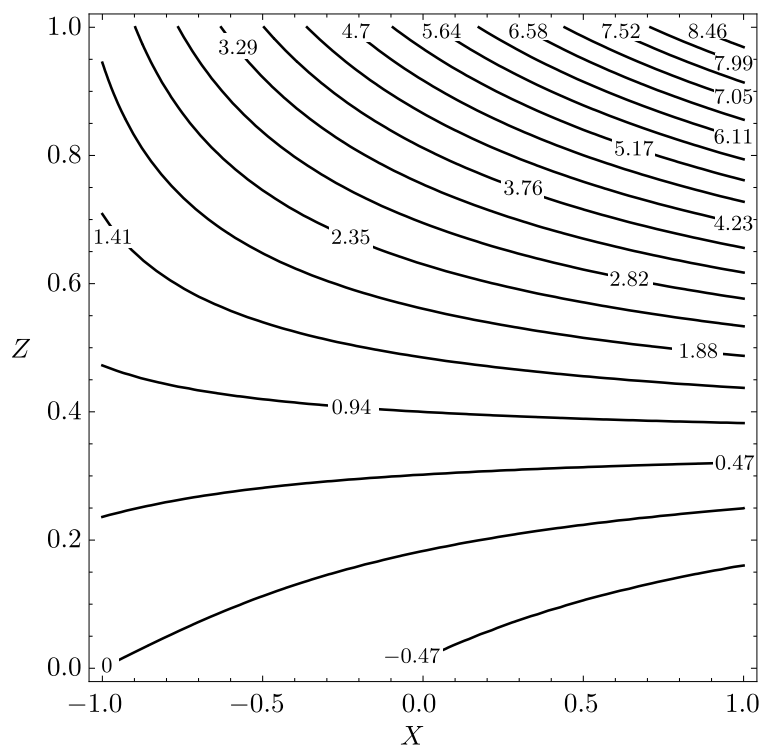

Figure 8. Pressure isolines

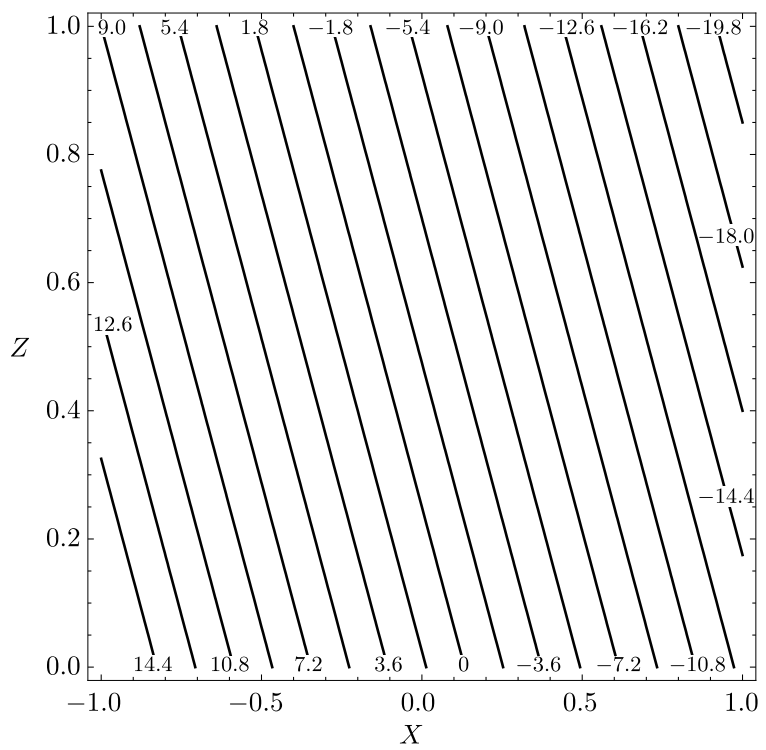

Figure 9. Temperature isolines

4. Conclusion. In this paper we have obtained an exact solution for the stationary case of the convective flow of an infinite layer of a viscous incompressible fluid. The Navier-Stokes equation in the Boussinesq approximation has been considered. The existence of stagnant points and counterflows in the fluid layer has been shown for the given values of temperature, pressure, their gradients, and velocities at the fluid layer boundaries.

The conditions imposed on the dimensionless similarity criteria for the existence of several stagnant points in the fluid layer have been written for the system of fluid flow equations reduced to a dimensionless form. 
Competing interests. We declare that we have no conflicts of interest in the authorship and publication of this article.

Authors' contributions and responsibilities. Each author has participated in the article concept development and in the manuscript writing. The authors are absolutely responsible for submitting the final manuscript in print. Each author has approved the final version of manuscript.

Funding. The work was done within the state assignment from FASO Russia, theme No. AAAA-A18-118020790140-5.

\section{References}

1. Gershuni G. Z., Zhukhovitskii E. M. Convective Stability of Incompressible Fluids. Jerusalem, Keter Publishing House, 1976, vi+330 pp., https://ntrl.ntis.gov/NTRL/ dashboard/searchResults/titleDetail/PB255645.xhtml.

2. Drazin T. Introduction to Hydrodynamic Stability. Cambridge, Cambridge University Press, 2002, xviii+258 pp. doi : 10.1017/cbo9780511809064.

3. Andreev V. K., Gaponenko Ya. A., Goncharova O. N., Pukhnachev V. V. Mathematical Models of Convection, De Gruyter Studies in Mathematical Physics, vol. 5. Berlin, Boston, De Gryuter Publ., 2012, xvi+420 pp. doi : 10.1515/9783110258592.

4. Nepomnyashchy A., Simanovskii I., Legros J. C. Interfacial Convection in Multilayer System. New York, Springer-Verlag, 2012, xiii+498 pp. doi: 10.1007/978-0-387-87714-3.

5. Shtern V. Counterflows. Paradoxical Fluid Mechanics Phenomena. Cambridge, Cambridge University Press, 2012, xiv+470 pp. doi: 10.1017/CB09781139226516.

6. Aristov S. N., Shvarts K. G. Vortical Flows of the Advective Nature in a Rotating Fluid Layer. Perm, Perm State Univ., 2006, 155 pp. (In Russian)

7. Aristov S. N., Shvarts K. G. Vortical Flows in Thin Fluid Layers. Kirov, Vyatka State Univ., 2011, 207 pp. (In Russian)

8. Aristov S. N., Shvarts K. G. Convective heat transfer in a locally heated plane incompressible fluid layer, Fluid Dyn., 2013, vol.48, no.3, pp. 330-335. doi: 10.1134/s001546281303006x.

9. Aristov S. N., Knyazev D. V. Localized convective flows in a nonuniformly heated liquid layer, Fluid Dyn., 2014, vol. 49, no. 5, pp. 565-575. doi: 10.1134/S0015462814050020.

10. Ryzhkov I. I. Thermodiffusion in Mixtures: Equations, Symmetries, Solutions and their Stability. Novosibirsk, SB RAS Publ., 2013, 199 pp. (In Russian)

11. Sidorov A. F. Two classes of solutions of the fluid and gas mechanics equations and their connection to traveling wave theory, J. Appl. Mech. Tech. Phys., 1989, vol. 30, no. 2, pp. 197203. doi : $10.1007 / \mathrm{bf} 00852164$.

12. Andreev V. K., Cheremnykh E. N. The joint creeping motion of three viscid liquids in a plane layer: A priori estimates and convergence to steady flow, J. Appl. Ind. Math., 2016, vol. 10, no. 1, pp. 7-20. doi: 10.1134/S1990478916010026.

13. Vlasova S. S., Prosviryakov E. Yu. Two-dimensional convection of an incompressible viscous fluid with the heat exchange on the free border, Vestn. Samar. Gos. Tekh. Univ., Ser. Fiz.-Mat. Nauki [J. Samara State Tech. Univ., Ser. Phys. Math. Sci.], 2016, vol. 20, no. 3, pp. 567-577. doi: 10.14498/vsgtu1483.

14. Aristov S. N., Prosviryakov E. Yu. On one class of analytic solutions of the stationary axisymmetric convection Bénard-Maragoni viscous incompreeible fluid, Vestn. Samar. Gos. Tekh. Univ., Ser. Fiz.-Mat. Nauki [J. Samara State Tech. Univ., Ser. Phys. Math. Sci.], 2013, no. 3(32), pp. 110-118 (In Russian). doi: 10.14498/vsgtu1205.

15. Aristov S. N., Privalova V. V., Prosviryakov E. Yu. Stationary nonisothermal Couette flow. Quadratic heating of the upper boundary of the fluid layer, Rus. J. Nonlin. Dyn., 2016, vol. 12, no. 2, pp. 167-178 (In Russian). doi : 10.20537/nd1602001.

16. Privalova V. V., Prosviryakov E. Yu. Exact solutions for a Couette-Hiemenz creeping convective flow with linear temperature distribution on the upper boundary, Diagnostics, Re- 
source and Mechanics of Materials and Structures, 2018, no. 2, pp. 92-109 (In Russian). doi: 10.17804/2410-9908.2018.2.092-109.

17. Privalova V. V., Prosviryakov E. Yu. Steady convective Coutte flow for quadratic heating of the lower boundary fluid layer, Rus. J. Nonlin. Dyn., 2018, vol.14, no. 1, pp. 69-79 (In Russian). doi: 10.20537/nd1801007.

18. Aristov S. N., Prosviryakov E. Yu. Nonuniform convective Couette flow, Fluid Dyn., 2016, vol. 51, no. 5, pp. 581-587. doi: 10.1134/S001546281605001X.

19. Deryabina M. S., Martynov S. I. Periodic flow of a viscous fluid with a predetermined pressure and temperature gradient, Rus. J. Nonlin. Dyn., 2018, vol. 14, no. 1, pp. 81-97 (In Russian). doi: 10.20537/nd1801008.

20. Ostroumov G. A. Free convection under the condition of the internal problem, NASA Technical Memorandum 1407. Washington, National Advisory Committee for Aeronautics, 1958.

21. Birikh R. V. Thermocapillary convection in a horizontal layer of liquid, J. Appl. Mech. Tech. Phys., 1966, no. 7, pp. 43-44. doi: 10.1007/bf00914697.

22. Shliomis M. I., Yakushin V. I. The Convection in a Two-layer Binary System with Evaporation, Hydrodynamics, 1972, no. 4, pp. 129-140 (In Russian).

23. Aristov S. N., Prosviryakov E. Yu. A new class of exact solutions for three-dimensional thermal diffusion equations, Theor. Found. of Chem. Engin., 2016, vol. 50, no. 3, pp. 286293. doi : $10.1134 /$ S0040579516030027.

24. Pukhnachev V. V. Non-stationary analogues of the Birikh solution, Izv. Alt. Gos. Univ., 2011, no. 1-2, pp. 62-69 (In Russian).

25. Pukhnachev V. V. Exact solutions of the hydrodynamic equations derived from partially invariant solutions, J. Appl. Mech. Tech. Phys., 2003, vol.44, no. 3, pp. 317-323. doi: 10. 1023/A : 1023472921305.

26. Aristov S. N., Prosviryakov E. Yu., Spevak L. F. Nonstationary laminar thermal and solutal Marangoni convection of a viscous fluid, Comp. Cont. Mech., 2015, vol. 8, no. 4, pp. 445-456 (In Russian). doi : 10.7242/1999-6691/2015.8.4.38.

27. Goncharova O. N. Exact solution of linearized equations of convection of a weakly compressible fluid, J. Appl. Mech. Tech. Phys, 2005, vol.46, no. 2, pp. 191-201. doi: 10.1007/ s10808-005-0032-6.

28. Bratsun D. A., Vyatkin V. A., Mukhamatullin A. R. On exact nonstationary solutions of equations of vibrational convection, Comp. Cont. Mech., 2017, vol. 10, no. 4, pp. 433-444 (In Russian). doi: 10.7242/1999-6691/2017.10.4.35.

29. Burmasheva N. V., Prosviryakov E. Yu. A large-scale layered stationary convection of an incompressible viscous fluid under the action of shear stresses at the upper boundary. Velocity field investigation, Vestn. Samar. Gos. Tekh. Univ., Ser. Fiz.-Mat. Nauki [J. Samara State Tech. Univ., Ser. Phys. Math. Sci.], 2017, vol.21, no.1, pp. 180-196 (In Russian). doi: 10.14498/vsgtu1527.

30. Burmasheva N. V., Prosviryakov E. Yu. A large-scale layered stationary convection of a incompressible viscous fluid under the action of shear stresses at the upper boundary. Temperature and presure field investigation, Vestn. Samar. Gos. Tekh. Univ., Ser. Fiz.-Mat. Nauki [J. Samara State Tech. Univ., Ser. Phys. Math. Sci.], 2017, vol. 21, no. 4, pp. 736-751 (In Russian). doi: 10.14498/vsgtu1568.

31. Lin C. C. Note on a class of exact solutions in magneto-hydrodynamics, Arch. Rational Mech. Anal., 1957, vol.1, no.1, pp. 391-395. doi:10.1007/bf00298016; . doi: 10.1142/ 9789814415651_0022.

32. Aristov S. N., Knyazev D. V., Polyanin A. D. Exact solutions of the Navier-Stokes equations with the linear dependence of velocity components on two space variables, Theor. Found. Chem. Eng., 2009, vol.43, no. 5, pp. 642-662. doi: 10.1134/s0040579509050066.

33. Hiemenz K. Die Grenzschicht an einem in den gleichförmigen Flüssigkeit-sstrom eingetauchten geraden Kreiszylinder, Dingler's Politech. J., 1911, vol. 326, pp. 321-324.

34. Pukhnachev V. V. Group properties of the Navier-Stokes equations in the plane case, J. Appl. Math. Tech. Phys., 1960, no. 1, pp. 83-90. 
35. Aristov S. N., Knyazev D. V. Viscous fluid flow between moving parallel plates, Fluid Dyn., 2012, vol. 47, no. 4, pp. 476-61. doi: 10.1134/s0015462812040060.

36. Petrov A. G. Exact solution of the Navier-Stokes equations in a fluid layer between the moving parallel plates, J. Appl. Math. Tech. Phys., 2012, vol. 53, no. 5, pp. 642-646. doi : 10. 1134/S0021894412050021.

37. Tsai R., Huang J. S. Heat and mass transfer for Soret and Dufour's effects on Hiemenz flow through porous medium onto a stretching surface, Int. J. Heat Mass Trans., 2009, vol. 52, no. 9-10, pp. 2399-2406. doi : 10.1016/j.ijheatmasstransfer.2008.10.017.

38. Afify A. A. Similarity solution in MHD: effects of thermal diffusion and diffusion thermo effects on free convective heat and mass transfer over a stretching surface considering suction or injection, Commun. Nonlinear Sci. Numer. Simul., 2009, vol.14, no. 5, pp. 2202-2214. doi: $10.1016 / j . c n s n s .2008 .07 .001$.

39. Beg O. A., Bakier A. Y., Prasad V. R. Numerical study of free convection magnetohydrodynamic heat and mass transfer from a stretching surface to a saturated porous medium with Soret and Dufour effects, Comput. Mater. Sci., 2009, vol. 46, no. 1, pp. 57-65. doi: 10.1016/j. commatsci.2009.02.004.

40. Osalusi E., Side J., Harris R. Thermal-diffusion and diffusion-thermo effects on combined heat and mass transfer of a steady MHD convective and slip flow due to a rotating disk with viscous dissipation and Ohmic heating, Int. Commun. Heat Mass Trans., 2008, vol. 35, no. 8, pp. 908-915. doi: 10.1016/j.icheatmasstransfer.2008.04.011.

41. Prasolov V. V. Polynomials, Algorithms and Computation in Mathematics, vol. 11. Berlin, Springer-Verlag, 2004, xiv+301 pp. doi : 10.1007/978-3-642-03980-5. 
Вестн. Сам. гос. техн. ун-та. Сер. Физ.-мат. науки. 2018. Т. 22, № 3. С. $532-548$

УДК 532.51; 517.958:531.3-324

\title{
Точные решения Куэтта-Хименца для описания установившегося ползущего конвективного течения вязкой несжимаемой жидкости с учетом теплообмена
}

\author{
В. В. Привалова ${ }^{1}$, Е. Ю. Просвиряков ${ }^{1,2}$ \\ 1 Институт машиноведения УрО РАН, \\ Россия, 620049, Екатеринбург, ул. Комсомольская, 34. \\ 2 Уральский федеральный университет \\ им. первого Президента России Б. Н. Ельцина, \\ Россия, 620002, Екатеринбург, ул. Мира, 19.
}

\section{Аннотация}

Изучается установившееся ползущее конвективное течение вязкой несжимаемой жидкости в тонком бесконечном слое. Исследование течения жидкости основано на использовании класса точных решений для уравнений Обербека-Буссинеска в приближении Стокса. Поле скоростей описывается точным решением Хименца. Поле температуры и поле давление линейно зависят от горизонтальной (продольной) координаты, что соответствует классу точных решений Остроумова-Бириха. Конвективное движение вязкой несжимаемой жидкости индуцировалось касательными напряжениями на верхней проницаемой (пористой) границе и заданием теплового источника на нижней границе. Кроме того, на верхней границе учитывался теплообмен по закону Ньютона-Рихмана. Полученные точные решения описывают противотечения в жидкости, у которых количество застойных точек не превышает трех. Формирование противотечений в жидкости сопровождается отсосом (sucking) и вдувом (injection) жидкости через проницаемую границу. Наличие большего числа застойных точек формирует ячеистую структуру линий тока. Кроме того, поле скоростей, полученное при решении краевой задачи, характеризуется локализацией течения вблизи границ слоя жидкости (пограничный слой). Полученные в статье точные решения могут использоваться для решения нелинейной системы Обербека-Буссинеска. Показано, что при линеаризации системы Обербека-Буссинеска число Грасгофа может принимать большие значения, зависящие от показателя геометрической анизотропии.

\section{Научная статья}

(2) (ㄱ) Контент публикуется на условиях лицензии Creative Commons Attribution 4.0 International (https://creativecommons.org/licenses/by/4.0/deed.ru)

\section{Образец для цитирования}

Privalova V. V., Prosviryakov E. Yu. Couette-Hiemenz exact solutions for the steady creeping convective flow of a viscous incompressible fluid, with allowance made for heat recovery, Vestn. Samar. Gos. Tekhn. Univ., Ser. Fiz.-Mat. Nauki [J. Samara State Tech. Univ., Ser. Phys. Math. Sci.], 2018, vol. 22, no. 3, pp. 532-548. doi: 10.14498/vsgtu1638.

\section{Сведения об авторах}

Валентина Викторовна Привалова (10) http://orcid.org/0000-0002-8648-0900

кандидат физико-математических наук; научный сотрудник; сектор нелинейной вихревой гидродинамики; e-mail: valentprival@gmail.com

Евгений Юръевич Просвиряков (1) http://orcid.org/0000-0002-2349-7801

доктор физико-математических наук; заведующий сектором; сектор нелинейной вихревой гидродинамики; e-mail: evgen_pros@mail.ru 
Ключевые слова: противотечение, точное решение, приближение Стокса, застойная точка.

Получение: 25 июля 2018 г. / Исправление: 21 августа 2018 г. / Принятие: 3 сентября 2018 г. / Публикация онлайн: 4 октября 2018 г.

Конкурирующие интересы. Мы заявляем, что у нас нет конфликта интересов в авторстве и публикации этой статьи.

Авторский вклад и ответственность. Все авторы принимали участие в разработке концепции статьи и в написании рукописи. Мы несем полную ответственность за предоставление окончательной рукописи в печать. Окончательная версия рукописи была нами одобрена.

Финансирование. Работа выполнена в рамках государственного задания ФАНО, тема № AAAA-A18-118020790140-5. 